\title{
Origin of Friedreich's Disease in Quebec
}

\author{
A. Barbeau ${ }^{1}$, M. Sadibelouiz ${ }^{1,2}$, M. Roy ${ }^{1}$, B. Lemieux ${ }^{3}$, \\ J.P. Bouchard ${ }^{4}$, G. Geoffroy ${ }^{5}$
}

ABSTRACT: We have been able to trace 40 cases of classical Friedreich's disease from 14 previously unrelated French Canadian kindreds to one common ancestral couple arriving in New France in 1634: Jean Guyon and Mathurine Robin.

One member of this couple presumably introduced one gene for Friedreich's disease into the French Canadian population. This gene has now been traced over 12 generations to both parents of the present cases. We plan to use this knowledge to study the spectrum of clinical manifestations of this gene and to carry out gene chromosomal localization studies, using the techniques of linkage and of molecular biology. Such studies in rare autosomal recessive disorders have previously been judged to be almost impossible.

RÉSUMÉ: Nous avons réussi à retracer le couple ancestral commun à 40 cas de Friedreich classique provenant de 14 familles canadiennes-françaises préalablement non reliées. Ces ancêtres communs (Jean Guyon et Mathurine Robin) sont arrivés en Nouvelle-France en 1634. Un des deux membres du couple a présumément introduit un gène de Friedreich dans la population du Québec. Ce gène a maintenant été suivi sur 12 générations jusqu'aux deux parents de chacun des 40 cas présentement sous étude. Nous avons l'intention d'utiliser ces nouvelles connaissances pour étudier l'éventail des manifestations cliniques de ce gène et pour tenter de localiser le site chromosomique du gène à l'aide des techniques de linkage et de biologie moléculaire. De telles études étaient jusqu'ici considérées comme pratiquement impossibles pour des maladies autosomales récessives rares.

Can. J. Neurol. Sci. 1984; 11:506-509

The Province of Quebec is ideal for genealogical studies of diseases because most of its inhabitants ( 5 of the 6 millions) are of French extraction, originating from a pool of $70,000 \mathrm{immi}$ grants who crossed the Atlantic before 1760. Most of these immigrants are known and their descendants can be traced through all but complete church and/or civil records. Lately these records have been microfilmed and are in the process of being computarized for even easier access. Meanwhile documents such as "Le Dictionnaire Généalogique des Familles Canadiennes" (C. Tanguay, Editions Elysée); "Le Dictionnaire National des Canadiens Français, 1608-1760" (Institut Généalogique Drouin) and "Le Dictionnaire Généalogique des Familles du Québec" (R. Jetté, Presses de l'Université de Montréal, 1983) are available to researchers, in addition to hundreds of "Répertoire de Paroisses" for most of the Catholic Faith parishes.

These resources have been used previously in tracing the origin of various neurological diseases in Quebec, such as oculo-pharyngeal muscular dystrophy (Barbeau, 1966), familial agenesis of the corpus callosum with polyneuropathy (Andermann et al., 1972) and Huntington's chorea (Barbeau et al., 1964). A preliminary report from our group (Barbeau et al., 1976) attempted to trace the origin of Friedreich's disease in
French Canadians from the study of four kindreds ( 13 cases). The search led to a total of 10 possible "founding couples" having lived in Nouvelle France in the 17th Century. In the present paper we would like to publish further data which now permits the identification of one of these common ancestral couples as having presumably introduced the Friedreich gene into the French Canadian population.

\section{SubJeCts AND Methods}

Genealogical studies were initiated for 14 different French Canadian kindreds, including 40 cases of a recessive ataxia conforming to all the classical criteria for Friedreich's disease as defined by Geoffroy et al. (1976). These patients were seen in one or more of the five Ataxia Clinics maintained in the Province of Quebec by ' L'Association Canadienne de l'Ataxie de Friedreich", and were followed regularly by the authors. This is an ongoing study, and many more kindreds are still available, but genealogical data has not yet been gathered for them. No particular form of selection was used for the kindreds included in this study, except willingness to cooperate and proximity to the clinics. For each of the ataxia families, a control kindred

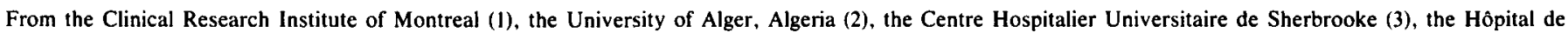
l'Enfant-Jésus, Québec (4), and the Hôpital Sainte-Justine, Montreal (5).

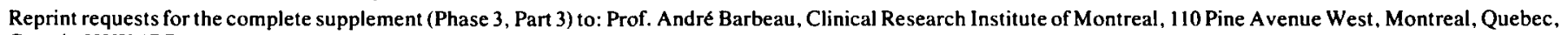
Canada H2W IR7. 
was also evaluated. These were selected at random from a pool of ongoing genealogical studies for other disorders in Quebec (Huntington's chorea, oculo-pharyngeal muscular dystrophy; dystonia musculorum deformans; myotonic dystrophy). None of the control kindreds were related to the ataxic kindreds, or contained known cases of spino-cerebellar or cerebellar disorders.

Genetic/genealogical studies in a recessive disorder are more difficult than in a dominant disease, for it is necessary to prove that both the father and the mother descend from the same common ancestral couple, since each is an obligatory heterozygote. A similar requirement was mandatory for the control kindreds. A complete family tree, in French Canada, goes back 10 to 13 generations to the days of the French Regime (1608-1760). The maximum number of ancestral couples for each kindred ( 13 generations), assuming no consanguinous marriages between the descendants, would be 2,048 . In fact the figure was always much lower, because the fertility rate of French Canadians in early colonial days was one of the highest in recorded history (Laberge, 1966) and the consanguinity rate always fairly high in isolated hamlets.

For each kindred, ataxic and control independently, each branch in the ascending tree was followed all the way to the original French immigrant and recorded on especially prepared charts. Once the trees were completed, an index card was made for each couple identified. Cards from all kindreds were compared for common names.

\section{RESULTS}

After the study of 3 kindreds, 22 common ancestral couples were known. After 4 kindreds, the list was down to 10 common ancestral couples (Barbeau et al., 1976). After 5 kindreds, there were 6 common couples and after 7 kindreds studied, the list included only one couple. The study of a further 7 ataxic kindred confirmed that only that couple was common to the ancestors of both the father and the mother in each family, and assured that this finding was highly significantly different from random occurence $(\pi<0.001)$.

Indeed, we searched for the presence of this couple among the ancestors of the 14 control kindreds. The couple was found on both maternal and paternal sides in only 3 instances. In a further 5 instances one branch of the family, only, could be traced to it.

In Fig. 1, we have illustrated the shortest possible genetic paths from the original couple to each of the 28 heterozygote parents of the 14 experimental kindreds. Much further work and many more patients would be necessary to prove beyond reasonable doubt that any one individual in the chain was in fact a carrier, because alternate paths exist as a result of consanguinous marriages, and are not illustrated on the chart. Moreover historical medical records have not yet been obtained, if they exist.

\section{DISCUSSION}

One could reasonnably ask why the interest in genealogical studies for Friedreich's disease, or any other hereditary disorder. We would like to propose the following arguments:

\section{(1) Historical reasons}

In autosomal dominant disorders, like Huntington's chorea and Machado-Joseph disease, it has been fascinating to follow the drift of the gene across continents and centuries. Thus the Huntington gene has been traced to the early pilgrims in the U.S.A. (Vessie, 1932), to Dutch immigrants in South Africa (Hayden, 1981), to Frenchmen from the region of La Rochelle in French Canada (Barbeau et al., 1964), to English immigrants in Australia (Wallace, 1972) and to East Anglia in Great Britain itself (Critchley, 1973). The gene for Machado-Joseph disease has been traced back from California or Massachussetts to the Azores, from the Azores to Portugal, and in Portugal itself to border villages between Portugal and Spain, and possibly to individuals of the Jewish faith fleeing from religious persecution in Spain (see Barbeau and Roy, 1984, this issue).

The ancestral couple presumably responsible for the introduction of one Friedreich gene into Quebec arrived in Nouvelle France in 1634; Jean Guyon was born in Saint-Aubin de Tourouvre in Perche (north-west of France) and was recruited by Robert Giffard (one of the first Seigneurs) as a mason. He was given part of the concession of Dubuisson near Beauport. He was married to Mathurine Robin, born in Mortagne, also in Perche. They had 10 children, 8 of which married.

It is not possible at this time to determine which member of the ancestral couple was the actual carrier of the Friedreich gene. That only one was such a carrier can be deduced from the fact that direct lines to the couple necessitate only the involvement of 4 of their 10 children, near the predicted $50 \%$.

It is obvious that our only justifiable conclusion is that Jean Guyon and Mathurine Robin are the only common ancestors of the 40 cases of Friedreich's ataxia studied. Whether other cases of Friedreich's ataxia in French Canada are derived from the same or from other sources will be determined only through further similar studies until all French Canadian cases have been accounted for.

\section{(2) Resolution of the heterogeneity problem}

Hereditary ataxias, particularly with autosomal dominant patterns of transmission, are notoriously variable in their presentation. Genetic/genealogical studies have helped in unravelling the question (for example see the article on MachadoJoseph disease, Barbeau and Roy, 1984, this issue). The problem is more complex in autosomal recessive disorders. Thus in the Province of Quebec (Barbeau, 1980) we have been able to distinguish clinical variants previously included within "Friedreich ataxia". In this way, we have recognized the "CharlevoixSaguenay Syndrome" (Bouchard et al., 1978), a previously unknown spastic ataxia; "Acadian Ataxia"' (Barbeau et al., 1984 , this issue) which is a slow progression form of areflexic recessive ataxia. We have also identified geographic isolates of more classical Friedreich, such as the Rimouski area (Bouchard et al., 1979). In fact the patients from this isolate are included among those studied in the present investigation.

The demonstration that 40 patients with the main features of classical Friedreich's ataxia all derive from a common source, will enable us to study the range of clinical presentations possible as expressions of a single gene. These patients are presently being reevaluated with the research protocole previously published by us (Pourcher and Barbeau, 1980). As new cases are identified, they will also be traced back to their ancestors. In this way, we may be able to find marriages between carrier descendants of possibly allelic genes (like Friedreich and Acadian Ataxia) and help resolve the problems of allelism and of heterogeneity in ataxia. 


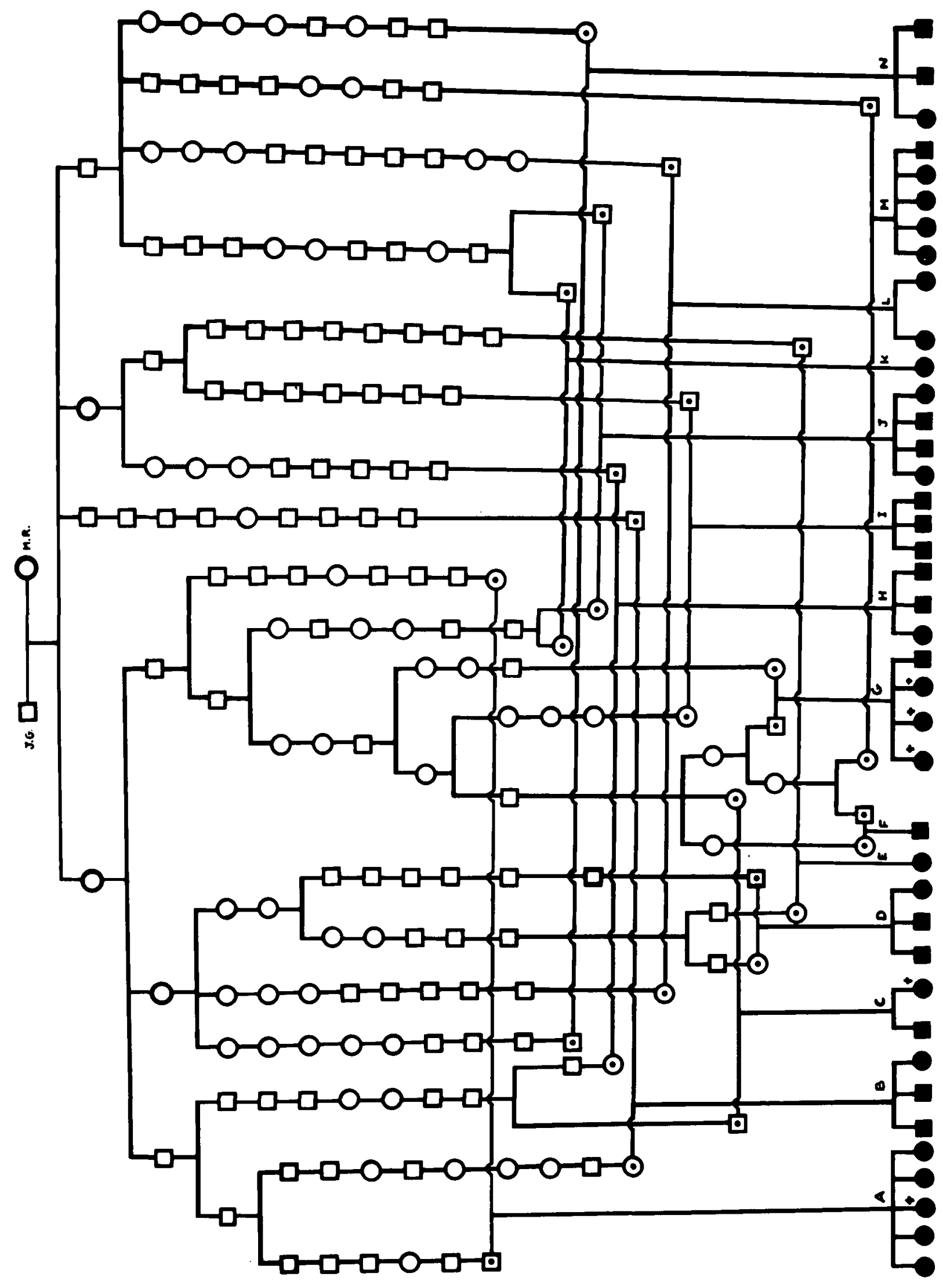

Figure 1 - Diagram showing that 40 cases of Friedreich's disease, in 14 kindreds, all descend from a common ancestral couple in French Canada. The most direct paths to the ancestor are illustrated, but other routes may also exist; thus it is still too early to assign carrier status to any individual, except to the obligatory heterozygotic parents, here identified by a dot within the circle or square. Full circles and squares indicate affected subjects. 


\section{(3) Molecular biology}

The availability of 40 cases of Friedreich's ataxia from a common ancestor, of their obligatory heterozygotes parents and of their relatives (normal or heterozygotes), will enable us to search for the chromosomal site of the Friedreich gene using conventional linkage studies and the powerful new techniques of molecular biology. These techniques have previously seldom been used in rare autosomal recessive disorders because one could not be sure to have eliminated heterogeneity between randomly obtained cases. We have already started the collection of blood and tissues from these patients in order to extract DNA for the above stated studies.

\section{ACKNOWLEDGEMENTS}

The studies reported in the present paper were supported by a general grant from "L'Association Canadienne de l'Ataxie de Friedreich". Our thanks are addressed to the patients and their families who supplied the initial impetus and many of the invaluable genealogical facts; to the numerous members of "La Société Généalogique canadienne française" who helped us across difficult hurdles in this study and particularly to the Librarian of the Society, Mrs. Marthe Beauregard. The authors would also like to thank Mrs. Nicole Guay-Poirier for typing the manuscript.

\section{REFERENCES}

Andermann F, Andermann E, Joubert M, Karpati G, Carpenter S, Melançon D (1972) Familial agenesis of the corpus callosum with anterior horn cell disease. A syndrome of mental retardation, areflexia and paraparesis. Trans Amer Neurol Assoc 97: 242-244.

Barbeau A (1966) La myopathie oculaire au Canada français - Etude préliminaire. J Gent Humaine suppl 15: 49-55.
Barbeau A (1980) Distribution of ataxia in Quebec. In: Spinocerebellar degeneration (Sobue I, ed.), Tokyo University Press, pp 120-142.

Barbeau A, Coiteux C, Trudeau JB, Fullum G (1964) La choree de Huntington chez les Canadiens français - Etude préliminaire. Union Med Can 93: 1178-1182.

Barbeau A, Le Siege M, Breton G, Coallier R, Bouchard JP (1976) Friedreich's ataxia: preliminary results of some genealogical research. Can J Neurol Sci 3: 303-306.

Barbeau A, Roy M (1984) The natural history of Machado-Joseph disease - An analysis of 138 personally examined cases. Can J Neurol Sci 11: pp (this issue).

Barbeau A, Roy M, Sadibelouiz M, Wilensky MA (1984) Recessive ataxia in Acadians and "Cajuns". Can J Neurol Sci 11: pp (this issue).

Bouchard JP, Barbeau A, Bouchard R, Bouchard RW (1978) Autosomal recessive spastic ataxia of Charlevoix-Saguenay. Can J Neurol Sci 5: 61-69.

Bouchard JP, Barbeau A, Bouchard R, Paquet M, Bouchard RW (1979). A cluster of Friedreich's ataxia in Rimouski, Quebec. Can J Neurol Sci 6: 205-208.

Critchley M (1973) Great Britain and the early history of Huntington's chorea. In: Huntington's chorea, 1872-1972 (Barbeau A, Chase TN and Paulson GW, eds), pp 13-17.

Geoffroy G, Barbeau A, Breton G, Lemieux B, Aubé M, Léger C Bouchard JP (1976) Clinical description and roentgenologic evaluation of patients with Friedreich's ataxia. Can J Neurol Sci 3: 279-286.

Hayden MR (1981) Huntington's Chorea. Springer-Verlag, New York, pp 1-192.

Laberge C (1966) Prospectus for genetic studies in the French Canadians, with preliminary data on blood groups and consanguinity. Bull Johns Hopkins Hosp 118: 52-68.

Pourcher E, Barbeau A (1980) Field testing of an ataxia scoring and staging system. Can J Neurol Sci 7: 339-344.

Vessie PR (1932) On the transmission of Huntington's chorea for 300 years. The Bures family group. J Nerv Ment Dis 76: 553-573.

Wallace DC (1972) Huntington's chorea in Queensland. A not uncommon disease. Med J Austral I: 299-307. 